\title{
Physical, Biochemical and Biological Characterization of Two Opposite Areas in the Southern Adriatic Sea (Mediterranean Sea)
}

\author{
Alessandra Campanelli ${ }^{1}$, Marina Cabrini ${ }^{2}$, Federica Grilli ${ }^{1}$, Daniela Fornasaro ${ }^{2}$, Pierluigi Penna ${ }^{1}$, \\ Zoran Kljajić ${ }^{3}$, Mauro Marini ${ }^{{ }^{*}}$ \\ ${ }^{1}$ CNR Institute of Marine Science, Ancona, Italy \\ ${ }^{2}$ OGS National Institute of Oceanography and Experimental Geophysics, Trieste, Italy \\ ${ }^{3}$ Institute of Marine Biology Kotor, University of Montenegro, Podgorica, Montenegro \\ Email: ${ }^{*}$ m.marini@ismar.cnr.it
}

Received November 23, 2012; revised February 19, 2013; accepted March 2, 2013

Copyright (C) 2013 Alessandra Campanelli et al. This is an open access article distributed under the Creative Commons Attribution License, which permits unrestricted use, distribution, and reproduction in any medium, provided the original work is properly cited.

\begin{abstract}
The Drini and Manfredonia Gulfs were investigated in May 2008 and April 2009, respectively. The gulfs are located in the South Eastern (Gulf of Drini) and South Western (Gulf of Manfredonia) Adriatic Sea. The areas are partially influenced by two main Adriatic surface currents: the Eastern Adriatic Current-EAC that flows north-westward along the eastern side, and the Western Adriatic Current-WAC that flows south-eastward along the western side of the basin. The spatial variations of temperature, salinity, fluorescence, dissolved oxygen concentration, Coloured Dissolved Organic Matter-CDOM, nutrients, chlorophyll $a$ and phytoplankton composition parameters in the two areas were observed and compared. CDOM regulates the penetration of UV light into the sea and plays an important role in many hydrological and biogeochemical processes on the sea surface layer including primary productivity. The phytoplankton specific diversity of the Gulf of Manfredonia showed a spring community with dinoflagellates (21 taxa) as the main important fraction, coccolithophorales (6 taxa) and diatoms with 10 identified taxa. The phytoplankton distribution along the eastern coast showed a different biodiversity: a prevalence of dinoflagellates (58 taxa) included harmful microalgae such as Alexandrium, Dinophysis and Lingulodinium genus. Diatoms were less abundant, among them Pseudo-nitzschia was also reported which could include some potentially toxic species. Nanoplankton are ever abundant in offshore waters and an exceptional bloom of cyanobacteria was registered in Buna-Boyana estuary due to strong industrial impact. The gulfs showed similar physical and biochemical characteristics despite the WAC carried out along the western Adriatic Sea the water rich in nutrients from the major northern Italian rivers. No correlations were found between CDOM and chlorophyll $a$ in the two areas and this implied that, probably, the primary source of CDOM might come from terrestrial input rather than the biological production from phytoplankton. The Gulf of Drini is impacted by the runoff of the Buna-Bojana River that makes this gulf an eutrophic area despite the mostly eastern side of the Adriatic being an oligotrophic basin.
\end{abstract}

Keywords: Adriatic Sea; Nutrients; Dissolved Organic Matter; Phytoplankton; Temperature

\section{Introduction}

The Southern Adriatic Sea extends approximately from the Pelagosa sill to the Otranto Strait [1]. It is characterized by a wide depression more than $1200 \mathrm{~m}$ deep and exchanges water with the Mediterranean Sea through the Otranto Strait where the sill depth is about $800 \mathrm{~m}$. The general circulation of the Southern Adriatic Sea is characterized by two coastal currents of surface waters flow-

"Corresponding author. ing from the North along the western side and from the South along the eastern side [2,3]. The current along the western side transports relatively fresh water along the western boundary from the North Adriatic (WACWestern Adriatic Current), one of the most productive areas of the Mediterranean [4,5]. The current along the eastern coast (SEAd-South Eastern Adriatic Current and $\mathrm{EAC}$-East Adriatic Current) comes from the central Mediterranean Sea (Ionian Sea), one of most oligotrophic areas in the world [6], and it transports the Ionian Surface 
Water (ISW, at the surface) and the Levantine Intermediate Water (LIW; 200 $\mathrm{m}$ depth) along the eastern boundary northward into the Adriatic Sea [7]. Such water masses have different features, as the Adriatic surface waters show lower salinity and higher nutrient concentrations, while the Ionian surface waters are saltier and warmer [8-11]. As a consequence, the South Adriatic Sea is distinctly oligotrophic, except for the Italian coastal areas affected by the nutrient-rich waters descending southward [12]. On the other hand, [3] show that the eastern coastal side (Montenegrin and Albanian areas) also presents eutrophic waters. Deeper water, Modified Levantine Intermediate Water (MLIW), contains high levels of nitrate, but is deficient in phosphorus [13].

The quality of coastal waters is a very important and sensitive issue. The chemical, physical and biological processes occurring in coastal zones can modify the marine ecosystem conditions. The enrichment of water with nutrients (primarily nitrogen, silicon and phosphorus compounds) may result in the growth of algal biomass. In particular, light and nutrient levels in the surface layer were sufficient to sustain active phytoplankton growth in similar basins [14].

Light entering the ocean is absorbed by water, living and detrital particles, and dissolved materials $(<0.2 \mu \mathrm{m})$. Absorption by the latter component, also known as Coulored Dissolved Organic Matter (CDOM), is almost exclusively attributable to humic substances. It is well known, that the abundance and distribution of CDOM in many coastal waters is dominated by terrestrial inputs from rivers and runoff as decomposition of terrestrial organic matter yields light-absorbing compounds such as, humic and fulvic acids [15-17]. In particular, CDOM is produced near the surface of the open ocean as a result of a heterotrophic process [18-21] and is destroyed by solar bleaching in stratified waters [17,22-25]. Despite this, the optical activity of CDOM is (almost) never completely eliminated by solar bleaching or other natural processes, indicating the presence of a pool of CDOM that is at least partially resistant to solar bleaching and microbial degradation. CDOM regulates the penetration of UV light into the sea and mediates photochemical reactions, therefore playing an important role in many biogeochemical processes on the ocean surface including primary productivity and the air-sea exchange of radiatively important trace gases [26-29]. The absorption of blue light by CDOM overlaps the phytoplankton absorption peak near $440 \mathrm{~nm}$, resulting in a competition between CDOM and phytoplankton for light in this region of the visible spectrum [30-32]. To define the relationship between phytoplankton abundances and the absorption by dissolved materials, CDOM absorption coefficients $\left(a_{\mathrm{CDOM}}(\lambda)\right)$ are compared with chlorophyll concentrations $[31,33]$.
Significant correlations between chlorophyll $a$ and $a_{\mathrm{CDOM}}$ $(\lambda)$ have been observed in eutrophic waters [34]. Generally, however, $a_{\mathrm{CDOM}}(\lambda)$ does not covary linearly with instantaneous estimates of pigment concentrations or phytoplankton productivity in coastal regions [35]. [33] hypothesized that such a covariation might exist if biological activity were averaged over a seasonal time period. [14] found that if CDOM concentrations in the surface layer were reduced, then the euphotic zone would extend to the bottom and conditions would be favourable for the substantial growth of the phytoplankton population. The trophic features of the water column directly influence the structure of the plankton communities [36] and, for the Adriatic, this result is evident in the East-West and South-North gradient of the primary production [37].

The main goal of this study is to characterise two opposite marine coastal areas located in the South Western (Gulf of Manfredonia) and in the South Eastern (Gulf of Drini) Adriatic Sea by using hydrological, biochemical, biological and CDOM data.

\section{Methods}

In the framework of the ADRICOSM-STAR (ADRIatic sea integrated river basin and COstal areaS management system: Montenegro coaSTal ARea and Bojana river catchment) and the MEDPOL (MEDiterranean POLlutants) projects two oceanographic surveys were carried out in May 2008 and April 2009 respectively. The physical, biochemical and biological sampling was done in each station of the two areas Gulf of Manfredonia and Gulf of Drini (Figure 1) from the surface to the bottom depth. The two areas were sampled in different years and were slightly offset seasonally, but simultaneous observations for the two regions do not yet exist.

\subsection{Study Areas}

The Gulf of Manfredonia is a shallow area located in the western part of the southern Adriatic Sea characterized by peculiar biochemical and hydrological characteristics due to the coastal morphology and rivers input. It is located in a transition zone between the northern and southern Adriatic circulation. The offshore circulation in the southern Adriatic sea is characterized by a cyclonic current $[38,39]$ with seasonal variability [40,41]. Inside the gulf the circulation is mainly affected by winds, mainly N-NW and S-SE directions that generate cyclonic and anticyclonic gyres. The gulf is located in a sheltered area characterized by eutrophic water $[42,43]$ compared to the southward area with a lower concentration of nutrients [44]. The biochemical and hydrological characteristics of the gulf are affected by the coastal morphology, land inputs and Adriatic general circulation. The main 


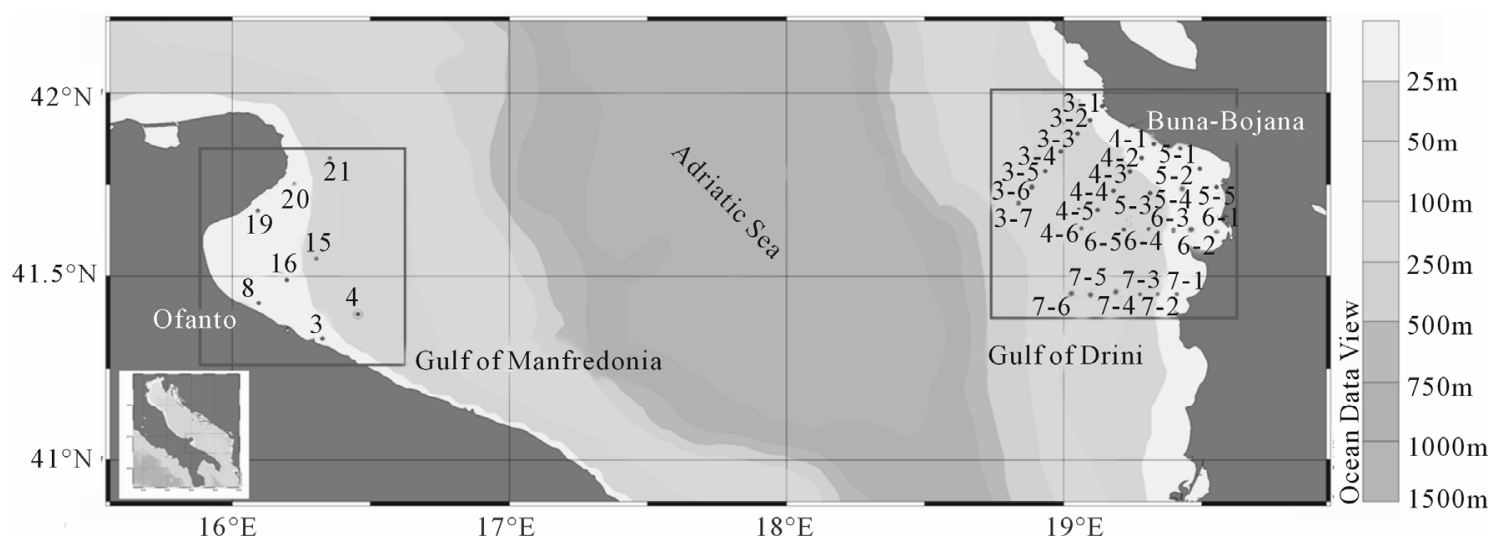

Figure 1. Study area showing the station locations in the Gulf of Manfredonia and in the Gulf of Drini stations (blue dots) and the bathymetry (colour shading).

river flowing into the gulf is the Ofanto with an average flow of $13.9 \mathrm{~m}^{3} \cdot \mathrm{s}^{-1}$ [45]. Other minor rivers that flow into the gulf are torrent-like and practically dry in summer. The gulf of Manfredonia can be considered a complex area under the potential threats of various wastes mainly deriving from urban and agricultural activities [46].

On the other hand, the river discharges of Northern Italy, mainly Po (monthly mean discharge $1500 \mathrm{~m}^{3} \cdot \mathrm{s}^{-1}$, $28 \%$ of the total annual runoff in the Adriatic Sea; $[47,48])$, also have a strong impact on the physical and biochemical conditions of the western side of the Adriatic Sea.

The Gulf of Drini is a shallow area located in the eastern part of the southern Adriatic Sea. It is characterized by significant eutrophic freshwater inputs particularly from the Buna/Bojana river [3]. The Buna/Bojana river has the largest single discharge (about $700 \mathrm{~m}^{3} \cdot \mathrm{s}^{-1}$ ) and the combined discharge of all Albanian rivers is about $1250 \mathrm{~m}^{3} \cdot \mathrm{s}^{-1}$ [49]. [3] shows that during spring the south eastern Adriatic coastal circulation is characterized by a northward current (SESC - South Eastern Shelf Coastal current). This current is at the seaward edge of the Buna/Bojana area and it is parallel but distinct from the SEAd current which hugs the shelf slope and to which it reconnects after the Boka Kotorska Bay, when the extended shelf of the south eastern Adriatic ends. The combination of natural and anthropogenic nutrients discharged from the south eastern Adriatic have the effect that the gulf of Drini may be considered an euthropic area like the areas located in the north western Adriatic in front of the Po River [3].

\subsection{Water Analysis}

Oceanographic measurements were collected in the Gulf of Drini and in the Gulf of Manfredonia at several stations inside the gulfs (Figure 1) during two cruises, carried out aboard the R/V G. Dallaporta in May (10 - 17) 2008 and in April (21 - 26) 2009, respectively.

The CTD (Conductivity-Temperature-Depth) data were collected at all the stations with a SeaBird Electronics SBE 911-plus CTD, equipped with additional sensors for dissolved oxygen (SBE43) and in situ fluorescence + turbiditimetry (Turner-SCUFA). The $24 \mathrm{~Hz}$ CTD data were processed according to [50] standards, and pressure-averaged to $0.5 \mathrm{db}$ intervals. Water samples were obtained by the upcasts with a SeaBird Carousel rosette water sampler equipped with 10-litre Niskin bottles.

Samples of CDOM, chlorophyll $a$, nutrients and phytoplankton at the suitable depths and stations were collected.

To measure CDOM absorption, water samples were filtered through $0.2 \mu \mathrm{m}$ Nucleopore membrane filters, then stored in the dark under refrigeration $\left(4^{\circ} \mathrm{C}\right.$ to $\left.8^{\circ} \mathrm{C}\right)$ and analysed on board within 24 hours using a Perkin Elmer spectrophotometer $550 \mathrm{~A}$ model $(10 \mathrm{~cm}$ cuvette pathlength). Absorbance data are converted to absorption coefficient $\left(a_{\mathrm{CDOM}}\right)$ according to [51]:

$$
a_{\mathrm{cDom}}(\lambda)=(2.303 / l)\left[\mathrm{AB}_{s}(\lambda)-\mathrm{AB}_{b s}(\lambda)-\mathrm{AB}_{\text {null }}(\lambda)\right]
$$

where $l$ is the cuvette pathlength, $\operatorname{AB}_{s}(\lambda)$ is the optical density of the filtrate sample relative to purified water, $\mathrm{AB}_{b s}(\lambda)$ is optical density of a purified water blank treated like a sample relative to purified water, and $\mathrm{AB}_{\text {null }}(\lambda)$ is the apparent residual optical density at a long visible or near infrared wavelength where absorption by dissolved material is assumed to be zero.

Chlorophyll $a$ is measured by filtering 31 samples through $47 \mathrm{~mm} \mathrm{GF} / \mathrm{F}$ filters and immediately extracted with $5 \mathrm{ml}$ of acetone at $-22^{\circ} \mathrm{C}$. The analyses were carried out at the ISMAR-CNR laboratory with a Dionex UHPLC equippoand a $100 \mu \mathrm{l}$ sample injection loop. Pigment concentrations were determined by em- ploying a modification of the procedure developed by [52].

Nutrient samples were filtered $\left(\mathrm{GF} / \mathrm{F}\right.$ Whatman $\left.{ }^{\circledR}\right)$, 
stored at $-20^{\circ} \mathrm{C}$ in polyethylene vials and analysed at the ISMAR-CNR laboratory of Ancona. The nutrients (nitrate- $\mathrm{NO}_{3}$, orthophosphate- $\mathrm{PO}_{4}$ and orthosilicic acid$\left.\mathrm{Si}(\mathrm{OH})_{4}\right)$ were analysed with a Bran+Luebbe Autoanalyzer QUAATRO system, and the resulting data processed with the AACE ${ }^{\circledR} 6.0$ (Automated Analyzer Control and Evaluation) software. Nutrient concentrations were determined by applying a modification of procedures developed by [53].

Micro and nanophytoplankton samples $(250 \mathrm{ml})$ were fixed with $\mathrm{Ca}\left(\mathrm{HCO}_{3}\right)_{2}$ buffered formaldehyde (4\% final concentration). Samples were processed using sedimentation chambers according to $[54,55]$ and observed with a light inverted microscope (Zeiss, Axiovert 100) at 320 magnifications to determine and count all the cells belonging to both fractions.

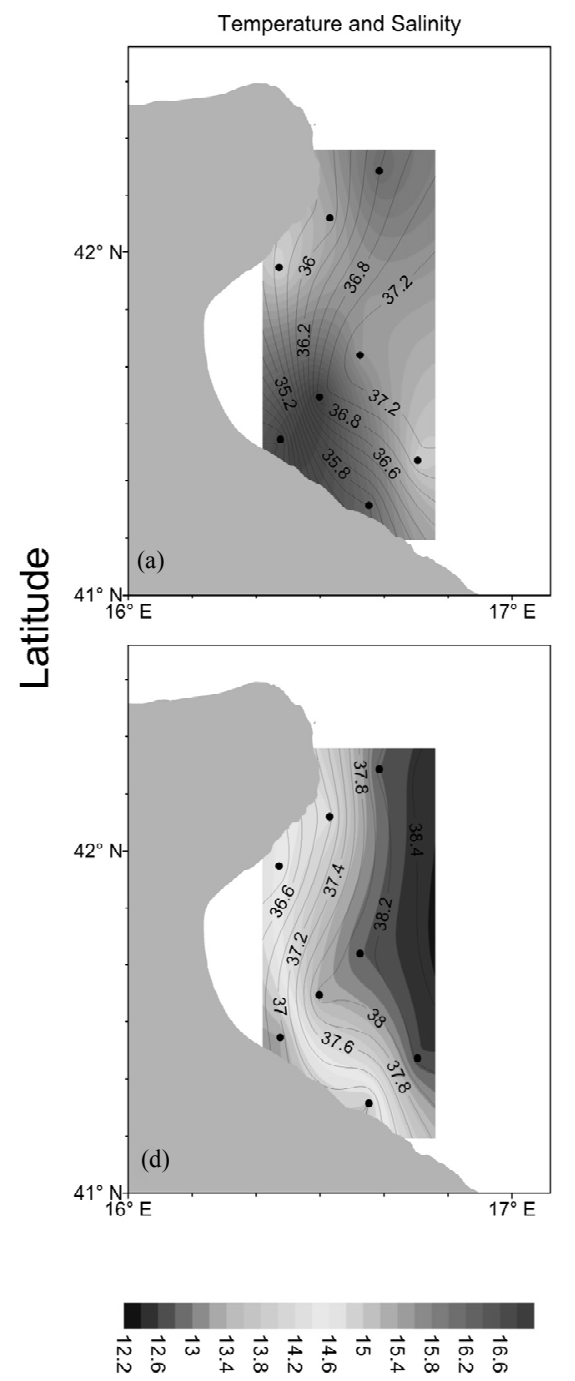

\section{Results and Discussion}

\subsection{Surface Distribution of Physical, Biochemical and Biological Parameters}

The Gulf of Manfredonia (Figures 2(a)-(c)) show surface water with low temperature $\left(14^{\circ} \mathrm{C}-16^{\circ} \mathrm{C}\right)$ and low salinity values $(34-36)$. Surface salinity increases from the coast to offshore waters and all the area is undersaturated (about $90 \%$ of oxygen saturation).

Nitrate concentrations show high values in inshore waters $\left(15-20 \mu \mathrm{mol} \cdot 1^{-1}\right)$ as opposed to orthosilicates concentrations which show the highest values in offshore waters. This feature points to the continental origin of nitrogen. Orthophosphates concentrations (not shown) are low in all the area $\left(0.02-0.05 \mu \mathrm{mol} \cdot \mathrm{l}^{-1}\right)$.

Fluorescence and Turbidity (not shown) show high values close to the coast probably due to the river dis-
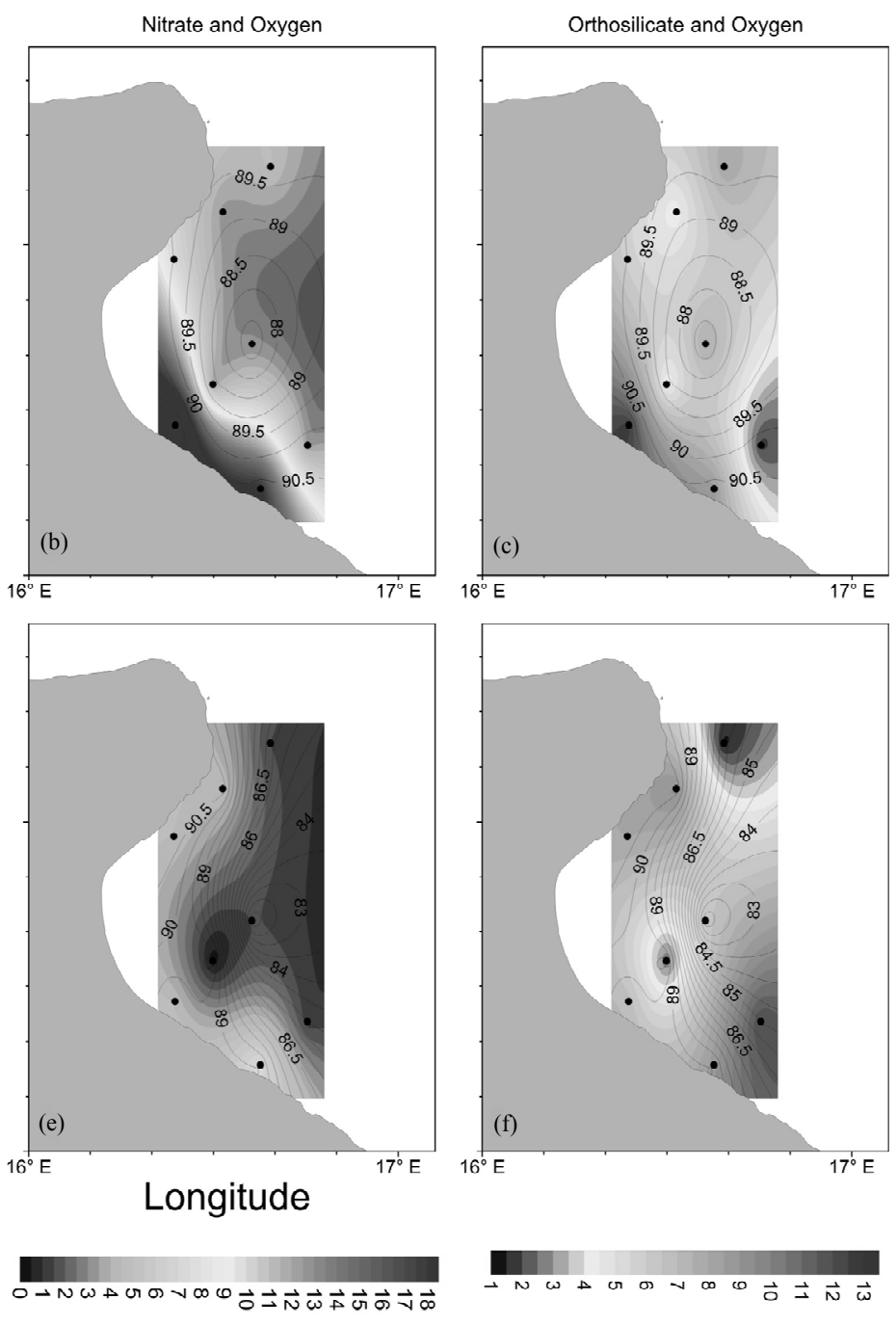

Figure 2. Surface ((a)-(c)) and bottom ((d)-(f)) distribution of temperature $\left({ }^{\circ} \mathrm{C}\right)$, nitrate $\left(\mu \mathrm{mol} \cdot \mathrm{I}^{-1}\right)$ and orthosilicate $\left(\mu \mathrm{mol} \cdot \mathrm{I}^{-1}\right)$ concentration (colored shading) in the Gulf of Manfredonia. The black contours represent the salinity ((a); (d): contour interval 0.2) and percentage of oxygen saturation ((b); (c); (e); (f): contour interval 0.5), and the dots represent the sampling points. The position of the stations is plotted in Figure 1. 
charges that could increase the primary production of the area $[11,56,57]$. The satellite image of chlorophyll (Figure 3) shows high values inside the gulf and a decrement of concentration from the coast to off-shore.

The biodiversity of phytoplankton functional groups shows a typical spring community with dinoflagellates as the most fraction (21 taxa) with Scrippsiella trochoidea, Oxytoxum variabile, Gonyaulax spinifera, Lessardia elongata as some significant species, while among the potentially toxic Prorocentrum minimum and Alexandrium spp. Diatoms are present with 10 taxa in which dominant are Cylindrotheca closterium, C. fusiformis and Navicula sp. and among coccolithophorales (6 taxa) Emiliania huxleyi, Rhabdosphaera claviger and Syracosphaera pulchra. In terms of abundance nanoflagellates, including criptophyceae, euglenophyceae, primnesiophyceae, prasinophyceae and undetermined forms, represent the main fraction almost in all the station. At the surface layer in station 8 , located in front of the river mouth, the total phytoplankton density reaches $2,654,264$ cells $\cdot 1^{-1}$ mostly sustained by nanoflagellates $(93 \%)$; dinoflagellates reaches a maximum value of 142,895 cells $\cdot l^{-1}$

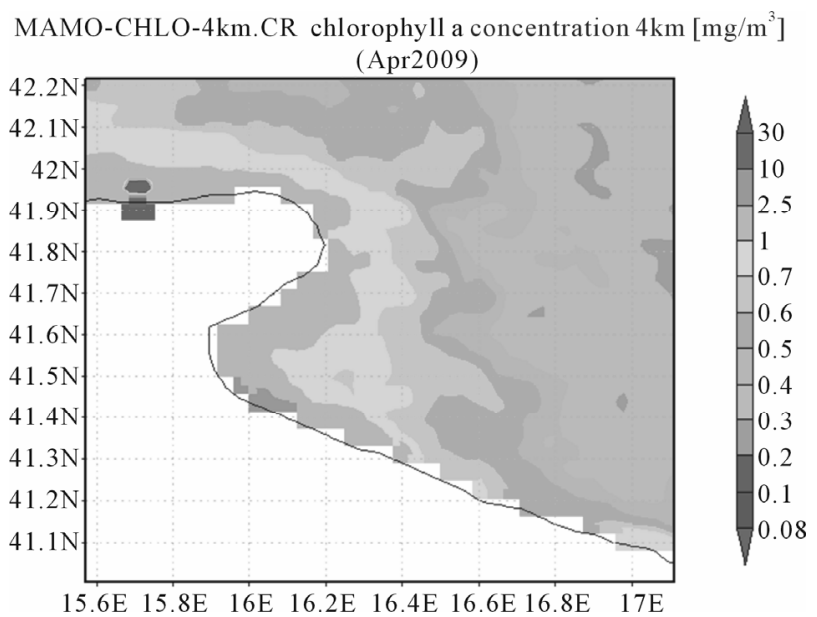

Figure 3. Modis-Aqua images of chlorophyll $a$ concentration (provided by NASA; $4 \mathrm{~km}$ resolution) for the periods 1th April to 30th April 2009 showing the sub-basin Gulf of Manfredonia. due to undetermined naked and thecatae forms (Table 1). In the same station, coccolithophorales also occur in higher abundance with 42,232 cells $\cdot \mathrm{l}^{-1}$. Diatoms abundance is very scarce (Table 1) in all the stations. In the other stations total phytoplankton ranges from between 240 and 430,000 cells $\cdot 1^{-1}$ including some heterotrophic forms (such as Protoperidinium) (Table 1). In fact, the satellite image shows a typical maximum value of chlorophyll in this area close to the river mouth (Figure 3).

In the gulf of Manfredonia [58] also show how the active phytoplankton is characterized by phytoflagellates in autumn, which are quantitatively the most important fraction, followed by diatoms, while dinoflagellates and coccolithophorids are less abundant groups.

The surface distributions of temperature and salinity in the Gulf of Drini (Figures 4(a)-(c)) show surface water which is less salty and warmer in comparison with the surface waters of the Gulf of Manfredonia. The area is characterized by inshore waters which are less salty than off-shore ones. In particular, this water mass, with a salinity lower than 36.5 , is found at the mouth of the river Buna-Bojana $\left(700 \mathrm{~m}^{3} \cdot \mathrm{s}^{-1}\right)$ located in the Drini Bay.

The highest values of oxygen and fluorescence (not shown) are recorded in the southern parts of the monitored area. Nutrient uptake by phytoplankton, especially diatoms, produce probably low nutrient concentrations in nearly all the area $[59,60]$.

The surface distributions of nutrients shows relatively high values only near the coast and, in particular, close to the Buna-Bojana mouth. For example, at the station 6 - 3 it is observed that low diatom abundances are coupled with relatively high nutrient values (nitrates: 2 - 4 $\mu \mathrm{mol} \cdot \mathrm{l}^{-1}$; orthosilicates: $4-6 \mu \mathrm{mol} \cdot \mathrm{l}^{-1}$ ).

Satellite image (Figure 5) shows lower chlorophyll concentrations in all the area in comparison with the Gulf of Manfredonia area. Furthermore, the highest concentrations of chlorophyll $a$ found at the Gulf of Drini are confined closer to the coast than at the Gulf of Manfredonia. This feature could be due to the presence of gyres inside the Gulf of Manfredonia inducted by the winds that redistributes the chlorophyll concentrations towards off-shore.

Table 1. Distribution of bacillariophyceae, dinophyceae, coccolithophorales and phytoflagellates (cells $\cdot \mathrm{I}^{-1}$ ) in the five monitored stations $(3,8,15,19$ and 21) in the gulf of manfredonia during May 2009.

\begin{tabular}{ccccccccccccc}
\hline & \multicolumn{2}{c}{ st. 3 } & \multicolumn{2}{c}{ st. 8} & \multicolumn{2}{c}{ st. 15 } & \multicolumn{2}{c}{ st. 19 } & \multicolumn{2}{c}{ st. 21 } \\
\cline { 2 - 11 } & Surface & Bottom & Surface & Bottom & Surface & Bottom & Surface & Bottom & Surface & Bottom \\
\hline DIATOMS & 2721 & 1200 & 1440 & 840 & 40 & 1080 & 5240 & 3480 & 3080 & 800 \\
DINOFLAGELLATES & 21,972 & 1240 & 142,895 & 320 & 8564 & 200 & 10,040 & 760 & 25,440 & 480 \\
COCCOLITHOPHORALES & 4923 & 880 & 42,232 & 280 & 11,286 & 0 & 720 & 360 & 3680 & 240 \\
PHYTOFLAGELLATES & 399,954 & 268,720 & $2,467,697$ & 248,040 & 221,610 & 306,000 & 350,248 & 180,320 & 398,416 & 260,120 \\
TOTAL & 429,570 & 272,040 & $2,654,264$ & 249,480 & 241,500 & 307,280 & 366,248 & 184,920 & 430,616 & 261,640 \\
\hline
\end{tabular}



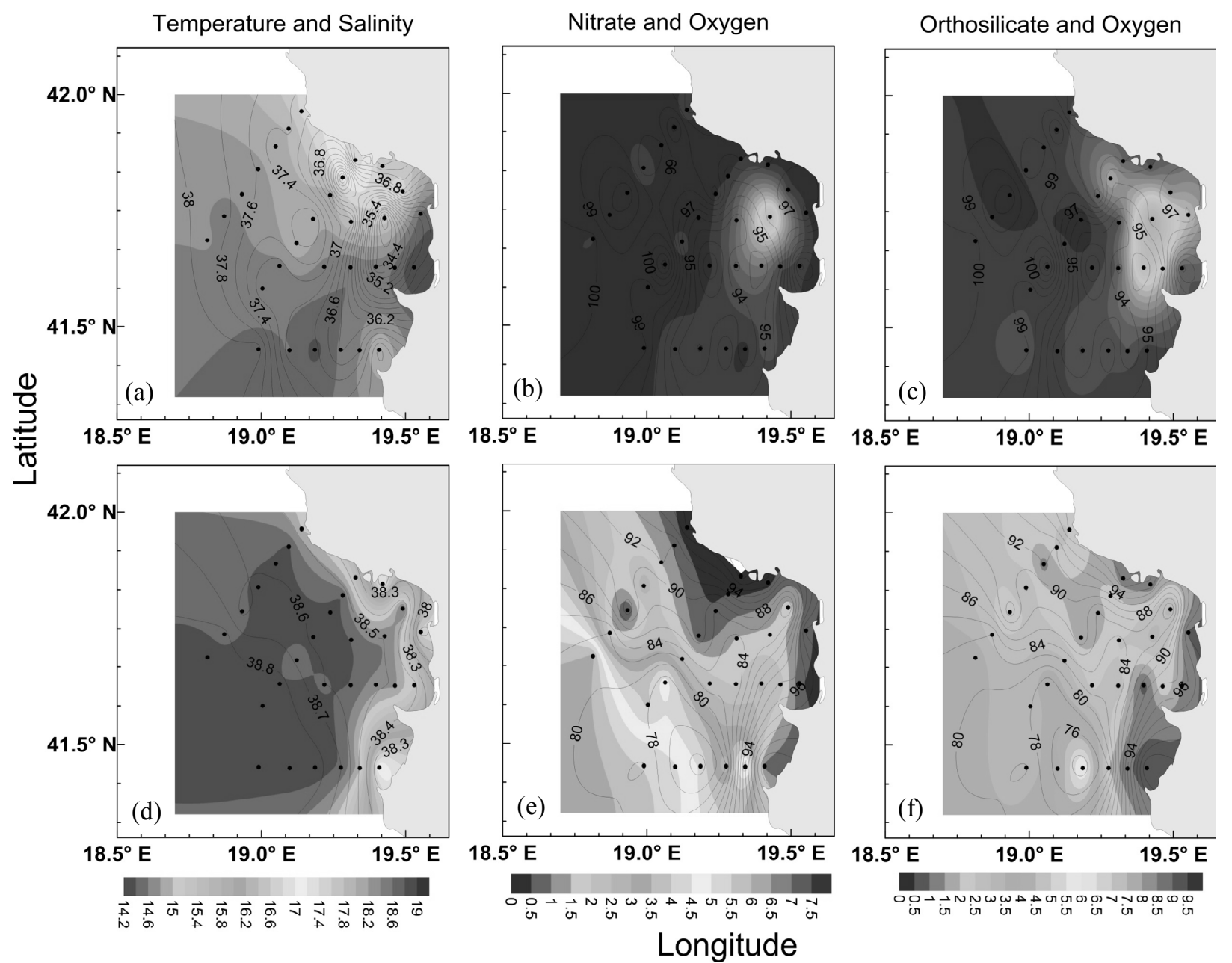

Figure 4. Surface ((a)-(c)) and bottom ((d)-(f)) distribution of temperature $\left({ }^{\circ} \mathrm{C}\right)$, nitrate $\left(\mu \mathrm{mol} \cdot \mathrm{I}^{-1}\right)$ and orthosilicate $\left(\mu \mathrm{mol} \cdot \mathrm{I}^{-1}\right)$ concentration (colored shading) in the Gulf of Drini. The black contours represent the salinity ((a), (d): contour interval 0.1) and percentage of oxygen saturation ((b); (c); (e); (f): contour interval 2), and the dots represent the sampling points. The position of the stations is plotted in Figure 1.

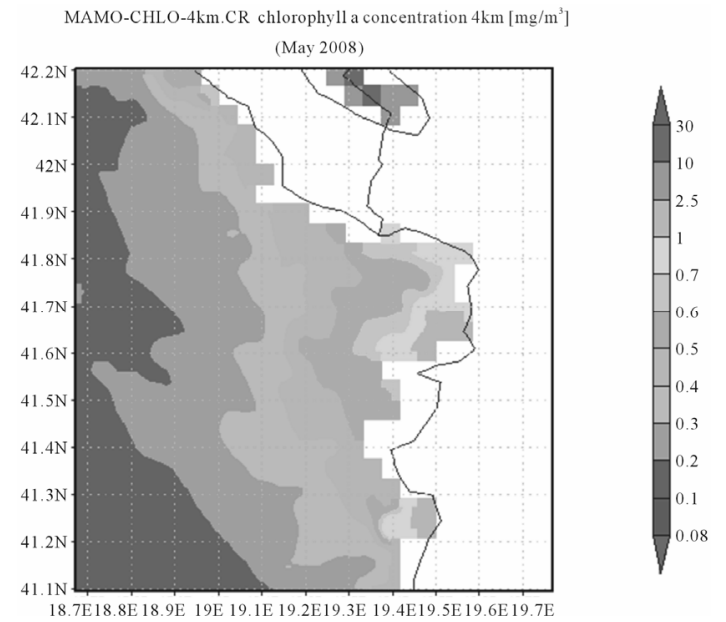

Figure 5. Modis-Aqua images of chlorophyll a concentration (provided by NASA; $4 \mathrm{Km}$ resolution) for the periods 1st May to 31st May 2008 showing the sub-basin Gulf of Drini.
[61].

The distribution of phytoplankton in the Gulf of Drini during May 2008, shows a different surface biodiversity: among dinoflagellates 58 taxa were found including potentially harmful microalgae such as Alexandrium, Dinophysis and Lingoludinium. Diatoms diversity included 9 taxa in which Thalassionema nitzschioides was the most frequent species. The abundance of the total microphytoplankton community was generally scarce and ranged from between 920 and 4260 cells $\cdot \mathrm{l}^{-1}$ (Tables 2(a) and (b)).

The nanoplankton fraction was generally more abundant in offshore waters in all the transects. An exceptional bloom of cyanobacteria with $5,720,000$ cells $\cdot 1^{-1}$ was registered in station 3.1 in the Buna-Bojana estuary; this value represents the highest concentration observed during the whole period and it was probably triggered by the river discharges in an area with a strong anthropic impact that influences the coastal waters particularly in 
Table 2. (a) Distribution of bacillariophyceae, dinophyceae and phytoflagellates $\left(\right.$ cells $\left.\cdot \mathrm{l}^{-1}\right)$ in the four monitored stations $(3-1$, 3 - 5, 4 - 1, 4 - 4) in the Gulf of Drini during April 2008; (b) Distribution of bacillariophyceae, dinophyceae and phytoflagellates (cells $\cdot \mathrm{I}^{-1}$ ) in the five monitored stations $(6-1,6-3,6-5,7-1$ and 7 - 4) in the Gulf of Drini during April 2008.

(a)

\begin{tabular}{ccccccccc}
\hline & \multicolumn{2}{c}{ st. 3-1 } & \multicolumn{2}{c}{ st. 3-5 } & \multicolumn{2}{c}{ st. 4-1 } & \multicolumn{2}{c}{ st. 4-4 } \\
\cline { 2 - 8 } & Surface & Bottom & Surface & Bottom & Surface & Bottom & Surface & Bottom \\
\hline DIATOMS & 400 & 160 & 100 & 0 & 300 & - & 220 & 380 \\
DINOFLAGELLATES & 20 & 40 & 140 & 140 & 60 & - & 180 & 0 \\
PHYTOFLAGELLATES & 600 & 2000 & 800 & 2260 & 680 & - & 1000 & 1720 \\
TOTAL & $5,721,040$ & 2200 & 1040 & 2400 & 1060 & - & 1400 & 2100 \\
\hline
\end{tabular}

(b)

\begin{tabular}{|c|c|c|c|c|c|c|c|c|c|c|}
\hline & \multicolumn{2}{|c|}{ st. 6 - 1} & \multicolumn{2}{|c|}{ St. 6 - 3} & \multicolumn{2}{|c|}{ st. 6 - 5} & \multicolumn{2}{|c|}{ st. 7 - 1} & \multicolumn{2}{|c|}{ st. 7 - 4} \\
\hline & Surface & Bottom & Surface & Bottom & Surface & Bottom & Surface & Bottom & Surface & Bottom \\
\hline DINOFLAGELLATES & 380 & 220 & 260 & 40 & 260 & 0 & 140 & - & 300 & 0 \\
\hline PHYTOFLAGELLATES & 1440 & 2800 & 600 & 3180 & 1600 & 1200 & 600 & - & 1400 & 1620 \\
\hline TOTAL & 4260 & 2400 & 920 & 3440 & 2080 & 1520 & 1420 & - & 1980 & 1920 \\
\hline
\end{tabular}

spring, when the contribution of freshwater is intense. Cyanobacteria are typical in estuarial and transitional waters and some species can sometimes produce toxic bloom [62] (Tables 2(a) and (b)). These taxa were previously described by $[58,63,64]$.

\subsection{Bottom Distribution of Physical, Biochemical and Biological Parameters}

The temperature and salinity distributions at the bottom in the Gulf of Manfredonia showed a bottom layer which was colder and saltier in comparison with the surface distributions (Figures 2(d)-(f)). The temperature decreases from the coast to off-shore while salinity increases. The oxygen saturation is quite similar at the surface layer with a value of about $90 \%-95 \%$ and the lowest oxygen saturation was detected in station $15(80 \%)$. The nitrate concentrations showed a gradient with values that decreased towards off-shore, as observed in the surface layer. The freshwater signal was less evident on the bottom layer. This feature was evidenced by nitrate concentrations which were lower in comparison with the surface ones (4 - $7 \mu \mathrm{mol} \cdot \mathrm{l}^{-1}$ alongshore). Orthosilicates showed a similar distribution and values compared to the surface (2 - $10 \mu \mathrm{mol} \cdot 1^{-1}$ ). Orthophosphate values (not shown) were very low in all the area $\left(0.02-0.05 \mu \mathrm{mol} \cdot \mathrm{l}^{-1}\right)$. The area did not seem to be characterized by processes of mineralization, probably due to the shallowness of the stations and to the water mixing. Furthermore, the cruise took place in early spring during the formation of thermocline and halocline which separates the different water masses
[10].

Microalgal fraction in the gulf of Manfredonia (Table 1) reaches lower abundances than at the surface. This is substantially due to phytoflagellates, while diatoms and dinoflagellates present both very low specific diversity and abundance (Table 1). The highest phytoplankton abundance is found in station 15 with 307,380 cells $\cdot 1^{-1}$ sustained by nanoflagellates $(99 \%)$ which is a typical community of deep and offshore waters. Diatoms are mainly found in coastal station 19 with a concentration of 3480 cells $\cdot 1^{-1}$ due to Cylindrotheca closterium and $C$. fusiformis and in station 3 with 1200 cells $\cdot l^{-1}$ mainly characterized by the same species. Dinoflagellates are always very scarce with a maximum of 1240 cells $\cdot l^{-1}$ reported in station 3 (Table 1). These observations were previously recorded by [58] in the same area.

The distribution of bottom temperature and salinity in the Gulf of Drini (Figures 4(d)-(f)) is more homogeneous in comparison with the surface ones. The station depths range from between $20 \mathrm{~m}$ and $200 \mathrm{~m}$ (Figure 1). At the stations close to the coast the highest values of temperature $\left(16.2^{\circ} \mathrm{C}-17.7^{\circ} \mathrm{C}\right)$ and the lowest values of salinity (37.9 - 38.4) were detected. The seasonal thermocline separates the surface layer, less salty and warmer, from the bottom layer. The off-shore and deepest stations detected the salinity values $(\geq 38.8)$ characteristic of the LIW described by [65] and which flows northward in this area [3,7].

Nutrient distributions show values that increase from the coast to off-shore. The deeper stations show the high- 
est values of nitrates $\left(4-5 \mu \mathrm{mol} \cdot \mathrm{l}^{-1}\right)$, orthosilicates (4 $\left.6 \mu \mathrm{mol} \cdot 1^{-1}\right)$ and orthophosphates $\left(0.1-0.2 \mu \mathrm{mol} \cdot 1^{-1}\right.$, not shown) corresponding to the lowest oxygen saturations $(73 \%-78 \%)$. These high nutrient values confirm the presence of the LIW [3] at depths of up to $120 \mathrm{~m}$.

The phytoplankton community (Tables 2(a) and (b)) in the Gulf of Drini is composed of low densities of diatoms and dinoflagellates while phytoflagellates are numerically the most important fraction. The abundance of total phytoplankton reaches a maximum of 4400 cells $\cdot 1^{-1}$ in station 6.1 due prevalently to phytoflagellates and diatoms with mainly Pseudo-nitzschia seriata, while the minimum value is found in offshore station 6.5 with 1520 cells $\cdot 1^{-1}$ sustained almost totally from phytoflagellates. The specific diversity of diatoms includes 10 taxa as in the surface layer and 8 for dinoflagellates including potentially toxic genuses, such as Alexandrium as previously observed by $[66,67]$ and [58].

\subsection{Colored Dissolved Organic Matter Absorption}

Absorbance of Colored Dissolved Organic Matter (CDOM) at $440 \mathrm{~nm}$ ranged from between 0.01 and 1.42 $\mathrm{m}^{-1}$ in the Gulf of Drini (May 2008) and between 0.04 and $0.97 \mathrm{~m}^{-1}$ in the Gulf of Manfredonia. Destruction of CDOM by exposure to sunlight releases compounds used for organism growth. CDOM was correlated with salinity and chlorophyll $a$ to try to understand its primary source. CDOM did not show a significant relationship with chlorophyll in the two gulfs as is sometimes observed in coastal areas [68]. In the Gulf of Manfredonia a positive correlation between $a_{\mathrm{CDOM}} 440$ and salinity was found ( $\left.\mathrm{n}=13, \mathrm{R}^{2}=0.5, \mathrm{p}>0.01\right)$ and that corresponding to a negative correlation between salinity and nitrate $(\mathrm{n}=$ $\left.20, \mathrm{R}^{2}=0.7, \mathrm{p}>0.01\right)$. This is linked to the importance of the continental inputs (mainly coming from the river discharge) in the distribution of organic matter inside the gulf. The input of pore waters during sediment resuspension events may also be locally important [69]. The correlation found between $a_{\mathrm{CDOM}} 440$ and salinity, however, supports the hypothesis that the local continental inputs are not the primary source of CDOM in this area as well as the primary production. Probably the detritus coming from the northern part of Italy is the source of CDOM found in the area and carried out by the WAC [10]. In fact, the primary source of CDOM along coast comes from the rivers and groundwater but the coastal water can also contain anthropogenic compounds coming from the river runoff, sewage discharge and other effluents [70]. Furthermore, during January-April 2009 the monthly Po River discharge, which has a strong impact on the conditions of the western Adriatic side [5], was $2295 \mathrm{~m}^{3} \cdot \mathrm{s}^{-1}$ and nearly two times superior to the monthly mean of January-April 1989-2008 which was $1250 \mathrm{~m}^{3} \cdot \mathrm{s}^{-1}$ [11] show how the filaments rich in nutrients and chlorophyll $a$ are detached from the coast north of the Gargano promontory. This kind of water mass, which could trigger the primary production and consequently the CDOM produced by phytoplankton, is carried toward the gulf of Manfredonia by the WAC and it mixes with the water mass present in this area $[1,12,39,40] .2009$ was characterized by a strong freshwater discharge from northern Italian rivers and so the physical and biochemical characteristics detected in the gulf were probably influenced by these peculiar conditions.

In spite of the fact that the Gulf of Drini did not show a clear correlation between salinity and CDOM, the source of CDOM probably came from the biological production by phytoplankton as well as from continental inputs of the river discharges. In [68] other similar correlations made in the Boka Kotorska Bay are described and, in that case, a positive correlation was found between CDOM and chlorophyll $a$ showing that in this area the biological production by phytoplankton appears to be the primary source of CDOM.

\section{Conclusions}

The two gulfs show similar physical and biochemical characteristics despite the fact that the Western Adriatic Current carries out, along the western Adriatic Sea, water rich in nutrients from the major northern Italian rivers.

The Gulf of Drini is impacted by runoff from the Buna-Bojana river which makes this gulf an eutrophic area in spite of the mostly eastern side of the Adriatic being an oligotrophic basin. The composition of phytoplankton in the two gulfs presents different biodiversity. The Gulf of Manfredonia shows a spring community with dinoflagellates as the most important functional group. The Gulf of Drini shows the prevalence of dinoflagellates including harmful microalgae such as Alexandrium, Dinophysis and Lingoludinium. Furthermore, a bloom of cyanobacteria was recorded in the Buna-Bojana estuary triggered by the strong anthropic impact.

No correlations were found between CDOM and chlorophyll $a$ in the two areas and this implies that, probably, the primary source of CDOM could have come from a terrestrial input rather than from the biological production from phytoplankton. Moreover, the positive correlation between salinity and CDOM in the Gulf of Manfredonia suggests that the CDOM does not come from local continental input but probably from the continental input coming from the northern Italian coast. These features show how the Gulf of Manfredonia is influenced by local inputs as well as input coming from northern Italian Rivers (mainly Po) that could have an impact on the physical and biochemical characteristics of the area, especially when the Po River discharges exceptional floods. 


\section{Acknowledgements}

We are grateful to the captain and the crew of R/V G. Dallaporta and Giuseppe Caccamo and Mattia Betti for their assistance with sample collection. The research was performed in the framework of the ADRICOSM-STAR program, coordinated by CMCC (Centro Euro-Mediterraneo per i Cambiamenti Climatici) and funded by the Italian Ministry of the Environment.

\section{REFERENCES}

[1] A. Artegiani, D. Bregant, E. Paschini, N. Pinardi, F. Raicich and A. Russo, "The Adriatic Sea General Circulation. Part I: Air-Sea Interactions and Water Mass Structure," Journal of Physical Oceanography, Vol. 27, No. 8, 1997, pp. 1492-1514. doi:10.1175/1520-0485(1997)027<1492:TASGCP $>2.0 . \mathrm{C}$ $\underline{\mathrm{O} ; 2}$

[2] B. B. Manca, V. Kovacevic, M. Gacic and D. Viezzoli, "Dense Water Formation in the Southern Adriatic Sea and Spreading into the Ionian Sea in the Period 1997-1999," Journal of Marine Systems, Vol. 33-34, No. 1, 2002, pp. 133- 154. doi:10.1016/S0924-7963(02)00056-8

[3] M. Marini, F. Grilli, A. Guarnieri, B. H. Jones, Z. Klajic, N. Pinardi and M. Sanxhaku, "Is the Southeastern Adriatic Sea Coastal Strip an Eutrophic Area?" Estuarine, Coastal and Shelf Science, Vol. 88, No. 3, 2010, pp. 395406. doi:10.1016/j.ecss.2010.04.020

[4] F. Grilli, M. Marini, D. Degobbis, C. R. Ferrari, P. Fornasiero, A. Russo, M. Gismondi, T. Djakovac, R. Precali and R. Simonetti, "Circulation and Horizontal Fluxes in the Northern Adriatic Sea in the Period June 1999-July 2002. Part II: Nutrients Transport," Science of the Total Environnement, Vol. 353, No. 1-3, 2005, pp. 115-125. doi:10.1016/j.scitotenv.2005.09.011

[5] A. Campanelli, F. Grilli, E. Paschini and M. Marini, "The Influence of an Exceptional Po River Flood on the Physical and Chemical Oceanographic Properties of the Adriatic Sea," Dynamics of Atmosphere and Oceans, Vol. 52, No. 1-2, 2011, pp. 284-297. doi:10.1016/j.dynatmoce.2011.05.004

[6] Y. Z. Yacobi, T. Zohary, N. Kress, A. Hecht, R. D. Robarts, M. Waiser, A. M. Wood and W. K. W. Li, "Chlorophyll Distribution throughout the Southeastern Mediterranean in Relation to the Physical Structure of the Water Mass," Journal of Marine Systems, Vol. 6, No. 3, 1995, pp. 179-190. doi:10.1016/0924-7963(94)00028-A

[7] P. M. Poulain and B. Cushman-Roisin, "Circulation," In: B. Cushman-Roisin, M. Gačič, P. M. Poulain and A. Artegiani, Eds., Physical oceanography of the Adriatic Sea. Past, Present and Future, Kluwier Academic Pub- lisher, Dordrecht, 2001, pp. 67-109. doi:10.1007/978-94-015-9819-4_3

[8] M. Zore-Armanda, "The System of Current in the Adriatic Sea," Studies and Reviews general Fisheries Council for the Mediterranean, Vol. 34, 1968, pp. 1-48.

[9] S. Fonda-Umani, "Successioni Fitoplanctoniche, Micro e Mesozoo Planctoniche Nell'Alto Adriatico," In: R. Marchetti and M. Cotta Ramusino, Eds., Proceedings of the
VSITE Conference, Milan, 1992, pp. 221-246.

[10] M. Zavatarelli, F. Raicich, D. Bregant, A. Russo and A. Artegiani, "Climatological Biogeochemical Characteristics of the Adriatic Sea," Journal of Marine Systems, Vol. 18, No. 1-3, 1998, pp. 227-263. doi:10.1016/S0924-7963(98)00014-1

[11] M. Marini, B. H. Jones, A. Campanelli, F. Grilli and C. M. Lee, "Seasonal Variability and Po River Plume Influence on Biochemical Properties along Western Adriatic Coast," Journal of Geophysical Research, Vol. 113, Article ID: C05S90, 2008. doi:10.1029/2007JC004370

[12] M. Orlic, M. Gacic and P. E. La Violette, "The Currents and Circulation of the Adriatic Sea," Oceanologica Acta, Vol. 15, No. 2, 1992, pp. 109-124.

[13] M. Marini, P. Fornasiero and A. Artegiani, "Variations of Hydrochemical Features in the Coastal Waters of Monte Conero: 1982-1990," Marine Ecology, Vol. 23, No. 1, 2002, pp. 258-271. doi:10.1111/j.1439-0485.2002.tb00024.x

[14] D. Mickee, A. Cunningham and K. J. Jones, "Optical and Hydrographic Consequences of Freshwater Run-Off during Spring Phytoplankton Growth in a Scottish Fjord," Journal of Plankton Research, Vol. 24, No. 11, 2002, pp. 1163-1171. doi:10.1093/plankt/24.11.1163

[15] N. K. Højerslev, "Yellow Substance in the Sea," In: J. Calkins, Ed., The Role of Solar Ultraviolet Radiation in Marine Ecosystems, Plenum, New York, 1982, pp. 263281. doi:10.1007/978-1-4684-8133-4_24

[16] K. L. Carder, R. G. Steward, G. R. Harvey and P. B. Ortner, "Marine Humic and Fulvic Acids: Their Effects on Remote Sensing of Ocean Chlorophyll," Limnology and Oceanography, Vol. 34, No. 1, 1989, pp. 68-81. doi:10.4319/10.1989.34.1.0068

[17] R. Del Vecchio and N. V. Blough, "Spatial and Seasonal Distribution of Chromophoric Dissolved Organic Matter (CDOM) and Dissolved Organic Carbon (DOC) in the Middle Atlantic Bight," Marine Chemistry, Vol. 89, No. 1-4, 2004, pp. 169-187.

[18] N. B. Nelson, D. A. Siegel and A. F. Michaels, "Seasonal Dynamics of Coloured Dissolved Organic Material in the Sargasso Sea," Deep Sea Research I, Vol. 45, No. 6, 1998, pp. 931-957. doi:10.1016/S0967-0637(97)00106-4

[19] N. B. Nelson, C. A. Carlson and D. K. Steinberg, "Production of Chromophoric Dissolved Organic Matter by Sargasso Sea Microbes," Marine Chemistry, Vol. 89, No. 1-4, 2004, pp. 273-287. doi:10.1016/j.marchem.2004.02.017

[20] D. K .Steinberg, N. B. Nelson and C. A. Carlson, "Production of Chromophoric Dissolved Organic Matter $(\mathrm{CDOM})$ in the Open Ocean by Zooplankton and the Colonial Cyanobacterium Tricodesmium spp.," Marine Ecology Progress Series, Vol. 267, 2004, pp. 45-56. doi: $10.3354 / \mathrm{meps} 267045$

[21] Y. Yamaschita and E. Tanoue, "In situ Production of Chromophoric Dissolved Organic Matter in Coastal Environment," Geophysical Research Letters, Vol. 31, 2004.

[22] S. Determan, R. Reuter and R. Willkomm, "Fluorescent Matter in the Eastern Atlantic Ocean. Part. 2: Vertical Profiles and Relation to Water Masses," Deep Sea Research I, Vol. 43, No. 3, 1996, pp. 345-360. 


\section{doi:10.1016/0967-0637(96)00008-8}

[23] A. Vodacek, N. V. Blough, M. D. DeGrandpre, E. T. Peltzer and R. K. Nelson, "Seasonal Variation of CDOM and DOC in the Middle Atlantic Bight: Terrestrial Inputs and Photooxidation," Limnology and Oceanography, Vol. 42, No. 4, 1997, pp. 674-686. doi:10.4319/lo.1997.42.4.0674

[24] D. A. Siegel, S. Maritorema, N. B. Nelson, D. A. Hansell and M. Lorenzi-Kayser, "Global Distribution and Dynamics of Colored Dissolved and Detrital Organic Materials," Journal of Geophysical Research, Vol. 107, No. C12, 2002. doi:10.1029/2001JC000965

[25] D. A. Siegel, S. Maritorema, N. B. Nelson and M. J. Behrenfeld, "Independence and Interdependencies among Global Ocean Color Properties: Reassessing the Bio- Optical Assumption," Journal of Geophysical Research, Vol. 110, Article ID: C07011, 2005. doi:10.1029/2004JC002527

[26] K. Mopper, X. L. Zhou, R. J. Kieber, D. J. Kieber, R. J. Sikorski and R. D. Jones, "Photochemical Degradation of Dissolved Organic Carbon and Its Impact on the Oceanic Carbon Cycle," Nature, Vol. 353, No. 6339, 1991, pp. 60-62. doi:10.1038/353060a0

[27] K. R. Arrigo and C. W. Brown, "Impact of Chromophoric Dissolved Organic Matter on UV Inhibition of Primary Productivity in the Open Ocean," Marine Ecology Progress Series, Vol. 140, No. 1-3, 1996, pp. 207-216. doi:10.3354/meps140207

[28] R. G. Zepp, T. V. Callaghan and D. J. Erickson, "Effect of Enhanced Ultraviolet Radiation on Biogeochemical Cycles," Journal of Photochemistry and Photobiology B: Biology, Vol. 46, No. 1-3, 1998, pp. 69-82. doi:10.1016/S1011-1344(98)00186-9

[29] D. A. Toole and D. A. Siegel. "Light-Driven Cycling of Dimethilsulfide (DMS) in the Sargasso Sea: Closing the Loop," Geophysical Research Letters, Vol. 31, No. 9, 2004. doi:10.1029/2004GL019581

[30] T. J. Wrigley, J. M. Chambers and A. J. McComb, "Nutrient and Gilvin Levels in Waters of Coastal-Plain Wetlands in an Agricultural Area of Western Australia," Australian Journal of Marine Freshwater Research, Vol. 39, No. 5, 1988, pp. 685-694. doi:10.1071/MF9880685

[31] R. J. Davies-Colley, "Yellow Substance in Coastal and Marine Waters Round the South Island, New Zealand," New Zealand Journal of Marine Freshwater Research, Vol. 26, No. 3-4, 1992, pp. 311-322. doi:10.1080/00288330.1992.9516526

[32] J. T. O. Kirk, "Light and Photosynthesis in Aquatic Ecosystems," Cambridge University Press, New York, 1994. doi:10.1017/CBO9780511623370

[33] A. Bricaud, A. Morel and L. Prieur, "Absorption by Dissolved Organic Matter in the Sea (Yellow Substance) in the UV and Visible Domains," Limnology and Oceanography, Vol. 26, No. C12, 1981, pp. 45-53.

[34] O. V. Kopelevich and V. I. Burenkov, "Relation between the Spectral Values of the Light Absorption Coefficients of Sea Water, Phytoplankton Pigments, and the Yellow Substance," Oceanology, Vol. 17, No. 3, 1977, pp. 427-433.

[35] N. B. Nelson, D. A. Siegel and A. F. Michaels, "Seasonal
Dynamics of Colored Dissolved Material in the Sargasso Sea," Deep Sea Research Part I: Oceanographic Research Papers, Vol. 45, No. 6, 1998, pp. 931-957. doi:10.1016/S0967-0637(97)00106-4

[36] D. Vilicic and A. Vucak, "Microphytoplankton in the Strait of Otranto (Eastern Mediterranean)," Marine Biology, Vol. 123, No. 3, 1995, pp. 619-630. doi: $10.1007 / \mathrm{BF} 00349240$

[37] F. Giordani, W. Helder, E. Koning, S. Miserocchi, R. Danovaro and A. Malaguti, "Gradient of Benthic-Pelagic Coupling and Carbon Budgets in the Adriatic and Northern Ionian Sea," Journal of Marine Systems, Vol. 33, 2002, pp. 365-387. doi:10.1016/S0924-7963(02)00067-2

[38] V. Kovacevic, M. Gacic and P. M. Poulain, "Eulerian Current Measurement in the Strait of Otranto and in the Southern Adriatc," Journal of Marine Systems, Vol. 20, No. 1-4, 1999, pp. 255-278. doi:10.1016/S0924-7963(98)00086-4

[39] P. M. Poulain, "Adriatic Sea Surface Circulation as Derived from Drifter Data between 1990 and 1999," Journal of Marine Systems, Vol. 29, No. 1-4, 2001, pp. 3-32. doi:10.1016/S0924-7963(01)00007-0

[40] A. Artegiani, D. Bregant, E. Paschini, N. Pinardi, F. Raicich and A. Russo, "The Adriatic Sea General Circulation. Part II: Baroclinic Circulation Structure," Journal of Physical Oceanography, Vol. 27, No. 8, 1997, pp. 15151532.

doi:10.1175/1520-0485(1997)027<1515:TASGCP >2.0.C $\mathrm{O} ; 2$

[41] P. M. Poulain, "Drifter Observations of Surface Circulation in the Adriatic Sea between December 1994 and March 1996," Journal of Marine Systems, Vol. 20, No. 14, 1999, pp. 231-253. doi:10.1016/S0924-7963(98)00084-0

[42] G. Chiaudani, G. F. Gaggino, R. Marchetti and M. Vighi, "Caratteristiche Trofiche Delle Acque Costiere Adriatiche: Campagna di Rilevamento 1978-1979. CNR Progetto Finalizzato Promozione della qualità dell'Ambiente," Serie di Monografie, Vol. 8, pp. 1-235.

[43] V. Damiani, C. N. Bianchi, O. Ferretti, D. Bedulli, C. Morri, M. Viel and G. Zurlini, "Risultati di una Ricerca Ecoloica sul Sistema Marino Costiero Pugliese," Thalassia Salentina, Vol. 18, 1988, pp. 153-169.

[44] G. Bello, G. Marano and R. Vaccarella, "Molluschi di "Matte" Morta di Poseidonia Oceanica Delile del Litorale Barese," Quaderni dell'Istituto di Idrobiologia e acquacultura G. Brunelli, Vol. 23, 1982, pp. 23-25.

[45] U. Simeoni, "I litorali tra Manfredonia e Barletta (Basso Adriatico); Dissesti, Sedimenti, Problematiche Ambientali," Bollettino della società Geologica italiana, Vol. 111, No. 3-4, 1992, pp. 367-398.

[46] F. Fiesoletti, A. Specchiulli, F. Spagnoli and G. Zappalà, "A New Near Time Monitoring Network in the Gulf of Manfredonia-Southern Adriatic Sea," In: European Operational Oceanography: Present and future, Proceedings of 4th International Conference on EuroGOOS, Brest, France, 2005, pp. 782-792.

[47] P. M. Poulain and F. Raicich, "Forcings," In: B. Cushman-Roisin, M. Gačič, P.M. Poulain and A. Artegiani 
Eds., Physical oceanography of the Adriatic Sea, Past, Present and Future, Kluwier Academic Publisher, Dordrecht, 2001, pp. 45-65.

[48] S. Cozzi and M. Giani, "River Water and Nutrient Discharges in the Northern Adriatic Sea: Current Importance and Long Term Changes," Continental Shelf Research, Vol. 31, No. 18, 2011, pp. 1881-1893. doi:10.1016/i.csr.2011.08.010

[49] UNEP, "Mediterranean Action Plan (MAP), Implications of Climate Change for the Albanian Coast," Technical Reports Series, Vol. 98, 1996.

[50] UNESCO, "The Acquisition, Calibration and Analysis of CTD Data. A Report of SCOR WG 51," Technical papers in Marine Sciences, No. 54, 1988, pp. 1-59.

[51] B. G. Mitchell, M. Kahru, J. Wieland and M. Stramska, "Determination of Spectral Absorption Coefficient of Particles, Dissolved Material and Phytoplankton for Discrete Water Samples," In: G. S. Fargion, J. L. Mueller and C.R. McClain, Eds., Ocean Optics Protocols for Satellite Ocean Colour Sensor Validation, NASA Goddard Space Flight Centre, Greenbelt, 2003, pp. 39-64.

[52] S. W. Wrighit, S. W. Jeffrey, R. F. C. Mantoura, C. A. Llewellyn, T. Bjornland, D. Repeta and N. Welschmeyer, "Improved HPLC Method for the Analysis of Chlorophylls and Carotenoids from Marine Phytoplankton," $\mathrm{Ma}$ rine Ecology Progress Series, Vol. 77, 1991, pp. 183196.

[53] J. D. H. Strickland and T. R. Parsons, "A Practical Handbook of Seawater Analysis," Bulletin of Fishery Research, Vol. 167, 1972, pp. 1-310.

[54] H. Uternöhl, "Zur Vervolikommunung der Quantitative Phytoplankton, Methodik", Mitteilungen. Internationale Vereiningung fuer Theoretische und Angewandte Limnologie, Vol. 9, 1958, pp. 1-38.

[55] A. Zingone, C. Totti, D. Sarno, M. Cabrini, C. Caroppo, M. G. Giacobbe, A. Lugliè, C. Nuccio and G. Socal, "Fitoplancton Metodiche di Analisi Quali-Quantitativa," In: G. Socal, I. Buttino, M. Cabrini, O. Mangoni, A. Penna and C. Totti, Eds., Metodologie di Studio del Plancton Marino, Manuali e Linee Guida ISPRA, Roma, 2010, pp. 213-237.

[56] A. Campanelli, P. Fornasiero and M. Marini, "Physical and Chemical Characterization of Water Column in the Piceno Coastal Area (Adriatic Sea)," Fresenenius Environmental Bulletin, Vol. 13, No. 5, 2004, pp. 430-435.

[57] B. Gašparović, T. Djakovac, N. Tepić and D. Degobbis, "Relationships between Surface-Active Organic Substances, Chlorophyll $a$ and Nutrients in the Northern Adriatic Sea," Continental Shelf Research, Vol. 31, No. 10, 2011, pp. 1149-1160. doi:10.1016/j.csr.2011.04.010

[58] F. Rubino, O. D. Saracino, S. Moscatello and G. Belmonte, "An integrated Water/Sediment Approach to Study Plankton (a Case Study in the Southern Adriatic Sea)," Journal of Marine Systems, Vol. 78, No. 4, 2009, pp. 536-546. doi:10.1016/j.jmarsys.2008.12.023

[59] N. G. Beck, K. W. Bruland and E. L. Rue, "Short-Term Biogeochemical Influence of a Diatom Bloom on the Nutrient and Trace Metal Concentrations in South San Francisco Bay Microcosm Experiments," Estuaries, Vol. 25, No. 6A, 2002, pp. 1063-1076. doi:10.1007/BF02692204

[60] C. Llebot, Y. H. Spitz, J. Solé and M. Estrada, "The Role of Inorganic Nutrients and Dissolved Organic Phosphorus in the Phytoplankton Dynamics of a Mediterranean Bay A Modeling Study," Journal of Marine Systems, Vol. 83, No. 3-4, 2010, pp. 192-209. doi:10.1016/j.jmarsys.2010.06.009

[61] I. Vilibic, J. W. Book, G. B. Paklar, M. Orlic, V. Dadic, M. Tudor, P. J. Martin, M. Pasaric, B. Grbec, F. Matic, H. Mihanovic and M. Morovic, "West Adriatic Coastal Excursions into the East Adriatic," Journal of Marine Systems, Vol. 78, No. 1, 2009, pp. S132-S156.

[62] G. Cronberg, E. J. Carpenter and W. W. Carmichael, "Taxonomy of Harmful Cyanobacteria," In: G. M. Hallegraeff, D. M. Anderson and A. D. Cembella, Eds., Manual on Harmful Marine Microalgae, UNESCO, Paris, 2003, pp. 523-562.

[63] D. Vilicic, "Fitoplankton Jadrangskoga Mora," Skolska knjiga, Zagreb, 2002.

[64] M. Cabrini, D. Fornasaro, D. Virgilio, A. Campanelli, Grilli F. and M. Marini, "Biodiversità del Fitoplancton Lungo la Fascia Costiera Montenegrina Albanese," Biologia Marina Mediterranea, Vol. 16, No. 1, 2009, pp. 376377.

[65] I. Vilibic and M. Orlic, "Adriatic Water Masses, Their Rates of Formation and Transport Through the Otranto Strait," Deep Sea Research, Part I, Vol. 49, No. 8, 2002, pp. 1321-1340.

[66] D. Vilicic, I. Marasovic, D. Miokovic, "Checklist of phytoplankton in the eastern Adriatic Sea," Acta Botanica Croatia, Vol. 61, No. 1, 2002, pp. 57-91.

[67] N. Vuksanovic and S. Krivokapic, "Prilog Poznavanju Fitoplanktona Kotorskog Zaliva u Zimskoj Sezoni 2004,” Zbornik radova, Vol. 2, No. 1-2, 2005, pp. 347-350.

[68] A. Campanelli, A. Bulatovic, M. Cabrini, F. Grilli, Z. Kljajic, R. Mosetti, E. Paschini, P. Penna and M. Marini, "Spatial Distribution of Physical, Chemical and Biological Oceanographic Properties, Phytoplankton, Nutrients and Coloured Dissolved Organic Matter (CDOM) in the Boka Kotorska Bay (Adriatic Sea)," Geofizika, Vol. 29, No. 2, 2009, pp. 215-228.

[69] E. Boss, W. S. Pegau, J. R. V. Zaneveld and A. H. Bernard, "Spatial and Temporal Variability of Absorption by Dissolved Material at a Continental Shelf," Journal of Geophysical Research, Vol. 106, No. C5, 2001, pp. 94999507.

[70] P. G. Coble. "Marine Optical Biogeochemistry: The Chemistry of Ocean Color," Chemical Reviews, Vol. 107, No. 2, 2007, pp. 402-418. doi: $10.1021 / \mathrm{cr} 050350+$ 